\title{
EFEK PATAHAN WATUKOSEK PADA GEOMORFOLOGI KALI PORONG DENGAN METODE TAHANAN JENIS 2-D
}

\author{
Alif Prabawa Arwananda ${ }^{1)}$, Wien Lestari ${ }^{1)}$, Juan PGN Rochman ${ }^{1)}$, Alwi Husein ${ }^{2)}$ \\ 1)Jurusan Teknik Geofisika, FTSP, Institut Teknologi Sepuluh Nopember \\ ${ }^{2)}$ Badan Penanggulangan Lumpur Sidoarjo (BPLS) \\ e-mail: alifp.arwananda94@gmail.com
}

\begin{abstract}
Abstrak. Salah satu penyebab munculnya semburan lumpur Sidoarjo yang masih diperdebatkan hingga saat ini yaitu mengenai reaktivasi patahan watukosek. Studi yang telah dilakukan sebelumnya menunjukkan adanya manifestasi di permukaan akibat patahan Watukosek, contohnya pembelokan geomorfologi Kali Porong. Penelitian dengan menggunakan metode tahanan jenis 2-D dilakukan untuk memetakan patahan yang berada di daerah Kali Porong. Lintasan yang digunakan memiliki bentangan $400 \mathrm{~m}$ hingga $1100 \mathrm{~m}$ dengan arah Barat - Timur. Total panjang bentangan mencapai $\pm 3,210 \mathrm{~m}$ dari 4 lintasan dan kedalaman maksimum hingga $\pm 200 \mathrm{~m}$. Data pengukuran di inversi menggunakan RES2DINV dan dipetakan dengan menggunakan ZondRes2D.
\end{abstract}

Kata Kunci: patahan Watukosek; geomorfologi; Kali Porong; metode tahanan jenis

\begin{abstract}
Watukosek fault reactivation is one of a cause of the Sidoarjo mud volcano which still debated until today. Studies that has been done previously showed their surface manifestation due to Watukosek fault, for example the deflection of Porong River geomorphology. 2-D resistivity method is used to map near-surface fault around Porong River. Line of measurement used have a range between $400 \mathrm{~m}$ to $1100 \mathrm{~m}$ with West - East direction. The total length of 4 line is $\pm 3,210 m$ with maximum depth until $\pm 200 m$. Measurement data is inversed by using RES2DINV and mapped by using ZondRes2D.

Keywords: Watukosek fault; geomorphology; Porong River; resistivity method
\end{abstract}

\section{PENDAHULUAN}

Luapan lumpur di daerah Porong, Sidoarjo yang sekarang dikenal masyarakat dengan sebutan lumpur Sidoarjo (LuSi) memunculkan banyak asumsi mengenai penyebab keluarnya lumpur tersebut. Salah satu asumsi penyebab terjadinya semburan lumpur Sidoarjo yaitu akibat adanya reaktivasi patahan Watukosek yang dipicu oleh gempa Yogyakarta tanggal 27 Mei 2006 dengan jarak epicenter $\pm 250 \mathrm{~km}$ dari pusat semburan lumpur (Mazzini dkk, 2007; Mazzini dkk, 2009; Istadi dkk, 2008).

Keberadaan patahan Watukosek sendiri masih diragukan dikalangan peneliti karena, sebelum munculnya bencana lumpur Sidoarjo patahan Watukosek tidak ada dalam peta geologi (Widodo, 2016). Sedangkan, bukti penguat adanya patahan Watukosek yang memanjang mulai dari Gunung Penanggungan hingga Pulau Madura menurut Mazzini (2009) dan Abidin (2008) yaitu, adanya pembelokan pada jalur Kali Porong, dan orientasi arah patahan pada area pusat semburan.
Penelitian lebih lanjut dilakukan untuk menelusuri kondisi bawah permukaan pada area yang diduga memiliki pengaruh pada bentuk geomorfologi Kali Porong dengan menggunakan metode tahanan jenis.

Kelebihan metode tahanan jenis dibandingkan metode geofisika lainnya yaitu, tidak merusak kondisi permukaan, tingkat penetrasi arus listrik yang konsisten sesuai konfigurasinya, memiliki banyak konfigurasi untuk disesuaikan dengan targetnya (Herman, 2001), dan memiliki respons yang tinggi terhadap perubahan resistivitas antar lapisan (Sehah dkk, 2011) sehingga metode tahanan jenis dapat digunakan untuk memetakan kondisi geologis di daerah penelitian.

Penggunaan metode tahanan jenis memiliki parameter kontrol tersendiri dibandingkan metode geofisika lainnya, yaitu kedalaman penetrasi arus listrik dan nilai tegangan yang terukur/resolusi data (Bernard, 2003). Kedua parameter controlling tersebut dibatasi oleh konfigurasi yang digunakan dalam akuisisi tahanan jenis, sehingga penggunaan 
konfigurasi juga menentukan target objek yang akan dicari. Sehubungan dengan topik penelitian yang ditentukan, yaitu untuk menentukan kondisi bawah permukaan maka konfigurasi yang digunakan haruslah memiliki penetrasi yang dalam.

\section{TINJAUAN PUSTAKA}

\section{Fisiografi Regional}

Van Bemmelen (1949) mengelompokkan Jawa Timur menjadi empat zona yaitu, zona Rembang, zona Kendeng, zona Solo, dan zona Pegunungan Selatan. Zona Rembang merupakan zona yang terdiri atas endapan laut dangkal, sedimen klastik, dan batuan karbonat (Buranda, 1999). Zona ini merupakan punggungan terlipat dan membentuk antiklinorium memanjang arah Barat - Timur mulai dari Purwodadi, Jawa Tengah dan berakhir di pulau Madura. Sama seperti Zona Rembang, Zona Kendeng juga merupakan antiklinorium memanjang mulai dari Barat hingga Timur (Susilohadi, 1995). Zona ini terbentuk dari volkanogenik dan sedimen plagik. Lokasi penelitian kali porong terdapat pada Zona Kendeng Timur.

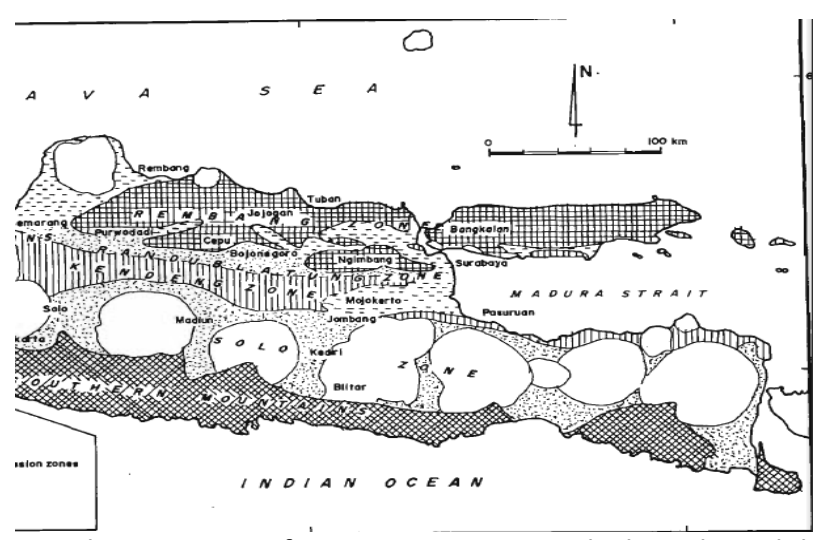

Gambar 1. Fisiografi Jawa Timur yang Dideskripsikan oleh van Bemmelen (Susilohadi, 1995).

\section{Metode Tahanan Jenis}

Pengambilan data dengan metode geofisika tahanan jenis memanfaatkan sifat tahanan jenis yang dimiliki oleh mineral atau fluida yang terkandung dalam suatu batuan atau lapisan. Pengambilan data tahanan jenis dimulai dengan mengalirkan arus listrik langsung (DC) ke bawah permukaan tanah melalui elektroda yang digunakan dalam suatu ruang berbentuk setengah bola. Prinsip dasar metode ini adalah mengalirkan arus listrik searah atau bolak-balik dengan frekuensi rendah kedalam bumi (Kuswanto, 2010). Hasil pengukuran tahanan jenis merupakan nilai tahanan jenis "semu", dimana nilai tahanan jenis tersebut memiliki asumsi bahwa kondisi di bawah permukaan bersifat homogen, sehingga akan memberikan nilai tahanan jenis yang sama dengan syarat konfigurasi elektroda yang digunakan juga sama.

Menurut Loke (1999) ada empat hal yang harus dipertimbangkan dalam menentukan konfigurasi elektroda yang digunakan yaitu, sensitivitas perubahan tahanan jenis secara vertikal dan horizontal, target kedalaman, cakupan data pengukuran horizontal, dan terakhir yaitu kekuatan sinyal (resolusi data).

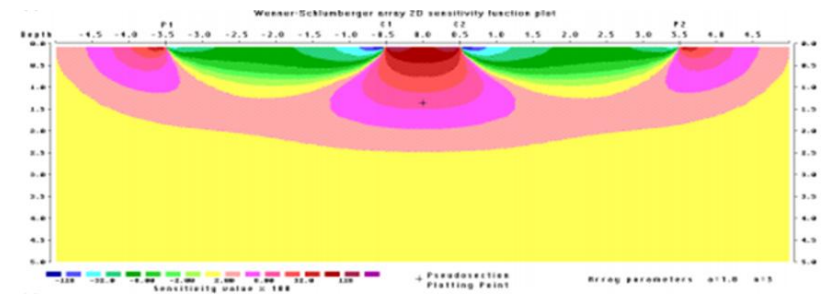

Gambar 2. Penampang Sensitivitas dengan Menggunakan Konfigurasi Wenner-Schlumberger (Loke, 1999).

Berdasarkan prinsip dasar tahanan jenis yang menggunakan Hukum Ohm, persamaan untuk hambatan jenis yaitu:

$$
\mathrm{R}=\frac{\mathrm{V}}{\mathrm{I}}
$$

dengan:

$\mathrm{V}$ melambangkan tegangan;

I melambangkan arus;

$\mathrm{R}$ melambangkan hambatan.

Hanya saja, yang diukur kali ini bukannya hambatan, melainkan tahanan jenis sehingga nilai yang diukur harus diganti menjadi tahanan jenis semu menjadi:

$$
\mathrm{P}=\frac{V}{I}
$$


Pada metode geolistrik, pengukuran potensial dilakukan dengan dua buah elektroda potensial (Finarani, 2013). Sehingga besar tegangan yang terukur menjadi:

$$
\Delta V=\frac{\rho I}{2 \pi}\left(\frac{1}{A 1 B 1}-\frac{1}{A 2 B 1}-\frac{1}{A 1 B 2}+\frac{1}{A 2 B 2}\right)
$$

dengan,

$$
K=\frac{2 \pi}{\left(\frac{1}{A 1 B 1}-\frac{1}{A 2 B 1}-\frac{1}{A 1 B 2}+\frac{1}{A 2 B 2}\right)}
$$

Sehingga, didapat persamaan tahanan jenis semu menjadi:

$$
P_{a}=K \frac{\Delta V}{I}
$$

\section{Inversi Least Square}

Inti dari metode least-square ini yaitu memberikan model dengan nilai perhitungan (atau error) terkecil, memiliki persamaan:

$$
m=\left(A^{T} A\right)^{-1} A^{T} d
$$

Metode inversi ditujukan untuk merekonstruksi model dari data observasi/pengukuran, atau bagaimana merubah data untuk menghasilkan suatu model. Inversi dapat digunakan untuk mengestimasi kualitas dari parameter model yang akan didapat, jenis parameter model, atau data yang paling baik dalam pembuatan model (tanpa gangguan/noise).

Selain meminimalisir perbedaan antara nilai tahanan jenis, metode inversi juga mengurangi parameter lainnya sehingga model yang dihasilkan sesuai dengan kondisi sesungguhnya. Untuk menemukan model yang sesuai dengan kondisi geologi yang ada, secara default RES2DINV menggunakan proses inversi smoothnessconstrained (deGroot-Hedlin dan Constable, 1990) yang memiliki persamaan:

$$
\left(J^{n_{T}} J+\mu F\right) d=J^{n_{T}} g-\mu F r
$$

dimana:

F melambangkan matrix untuk smoothing;

J melambangkan matrix Jacobian;

$r$ melambangkan vector logaritma dari model nilai tahanan jenis;

$\mu$ melambangkan faktor peredaman (damping);

d melambangkan vector gangguan;

$\mathrm{g}$ melambangkan vector perbedaan.

\section{METODOLOGI PENELITIAN}

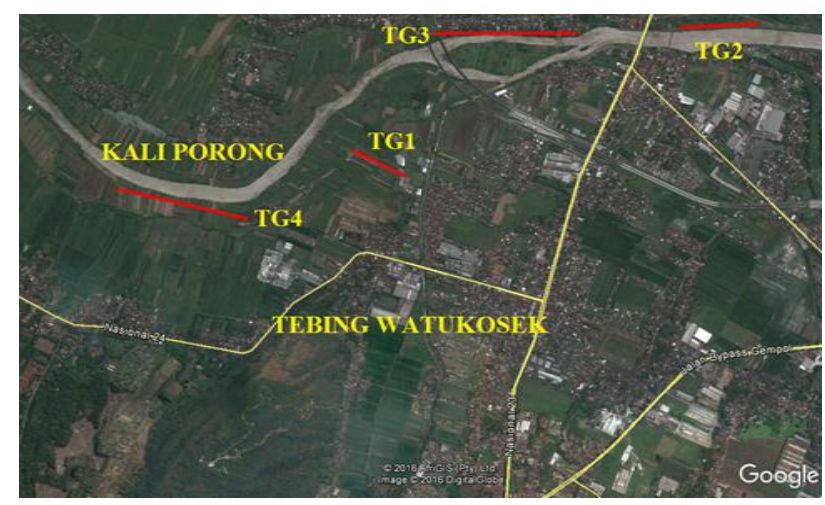

Gambar 3. Desain Lintasan Pengukuran.

Lokasi penelitian Tugas Akhir ini berada di daerah Selatan semburan gunung lumpur yang ditandai dengan garis merah (Gambar 3). Lintasan memanjang dari Barat menuju Timur mengikuti aliran Kali Porong.

Setelah pengukuran dilakukan di 4 lintasan, proses inversi dilakukan menggunakan RES2DINV dengan menggunakan parameter inversi sebagai berikut. 


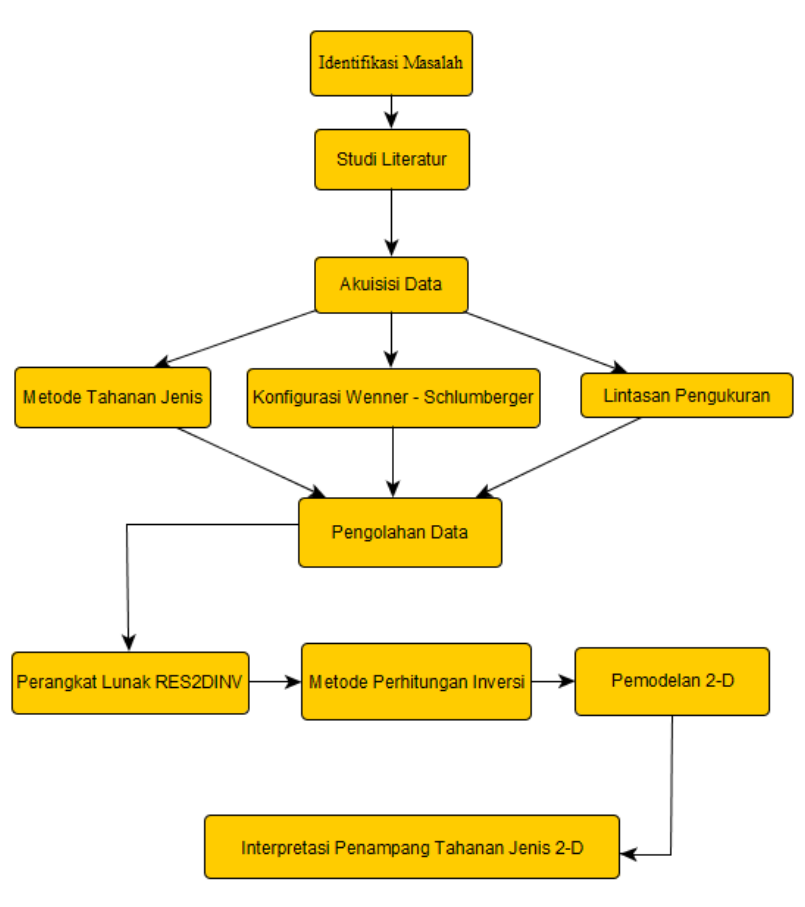

Gambar 4. Diagram Alir Proses Pengerjaan Penelitian.

Tabel 1. Parameterlinversi yang Digunakan di RES2DINV Selama Proses Pengolahan Data.

\begin{tabular}{|l|c|}
\hline \multicolumn{1}{|c|}{ Parameter Inversi } & Nilai \\
\hline Use model refinement & $\begin{array}{c}\text { Cells with width of } \\
\text { half the unit spacing }\end{array}$ \\
\hline Optimise damping factor & Yes \\
\hline $\begin{array}{l}\text { Vertical/Horizontal flatness } \\
\text { ratio }\end{array}$ & 1.0 \\
\hline Include smoothing & Yes \\
\hline Select robust inversion & $0.1 \%$ \\
\hline $\begin{array}{l}\text { Percentage change for line } \\
\text { search }\end{array}$ & 20 \\
\hline Number of iteration & Finest mesh; nodes \\
\hline $\begin{array}{l}\text { Type of mesh for forward } \\
\text { modelling }\end{array}$ & 0.1 \\
\hline Choose convergence limit & \\
\hline
\end{tabular}

\section{HASIL DAN PEMBAHASAN}

\section{Analisis Patahan}

Dari inversi 4 data pengukuran didapat penampang dengan kedalaman hingga $\pm 200 \mathrm{~m}$ dengan error antara 1.14\% - 3.4\%.
Anomali pada lintasan TG4 yang berada di kedalaman $55 m-150 m$ pada jarak pengukuran 560m-590m memiliki kecendrungan membentuk patahan normal fault dengan penurunan ke arah Timur, selain itu tren patahan tersebut terlihat terdorong ke arah Barat yang memotong lapisan air tanah (kotak hitam Gambar 9).

Penampang TG1, dan TG3 tidak memiliki anomali patahan walaupun lintasan pengukuran memotong dengan arah dugaan patahan Watukosek. Penampang TG2 tidak memiliki anomali patahan walaupun lintasan pengukuran tersebut berada di Selatan semburan lumpur Sidoarjo (TG2).

\section{Efek Patahan Terhadap Geomorfologi Kali Porong}

Tren patahan pada TG4 yang terdorong ke arah Barat pada jarak $720 m$ - 790m yang memotong lapisan air tanah diduga sebagai adanya pergeseran lapisan ke arah Barat yang mengikuti dorongan geomorfologi Kali Porong. Selain itu, lintasan tersebut memiliki indikasi adanya perluasan ketebalan muka air (resistivitas rendah) pada jarak $500 m$ - 90m dengan kedalaman awal 52.3m menjadi $73.8 \mathrm{~m}$ di bawah permukaan, hanya saja lintasan pengukuran tidak menangkap kemenerusan dari perluasan ketebalan muka air tersebut. Patahan Watukosek yang teridentifikasi pada lintasan TG4 searah dengan pembelokan Kali Porong.

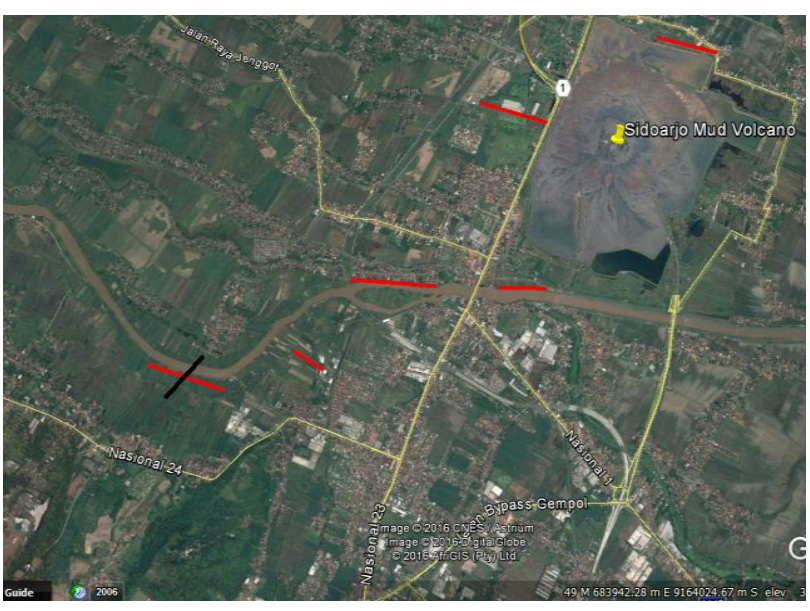

Gambar 5. Patahan yang Teridentifikasi (Garis Hitam). 


\section{PENUTUP}

\section{Kesimpulan}

Kesimpulan yang didapat dari penelitian ini adalah Lintasan TG4 yang terdekat dengan Kali Porong mengindikasikan adanya patahan yang melintasi daerah tersebut dan terdorongnya patahan ke arah Barat yang sama dengan geomorfologi Kali Porong.

\section{Saran}

Saran yang dapat diberikan berdasarkan hasil dan kesimpulan untuk membangun hipotesahipotesa selanjutnya adalah:

1. Perlunya diadakan survey metode geofisika yang memotong Kali Porong yang membelok.

2. Penambahan lintasan survey tahanan jenis di sekitar lintasan TG4 dan TG3.

\section{Ucapan Terima Kasih}

Penulis mengucapkan terima kasih kepada Pak Alwi Husein sebagai pembimbing dari Badan Penanggulangan Lumpur Sidoarjo (BPLS) untuk pengarahannya selama proses penelitian hingga penulisan artikel.

\section{DAFTAR PUSTAKA}

Abidin, H. Z., Davies, R. J., Kusuma, M. A., Andreas, H., \& Deguchi, T., 2008. Subsidence and Uplift of Sidoarjo (East Java) due to The Eruption of The Lusi Mud Volcano (2006-Present). Environmental Geology, hh. 833-844

Bernard, J., 2016, February 24). Heritage Geophysics Inc. Retrieved from HeritageGeophysics.com: http://www.heritagegeophysics.com/papers/Depth_ of_investigation.pdf

Buranda., 1990. Geologi Indonesia. Malang: Universitas Negeri Malang.

Herman, R., 2001. Introduction to Electrical Resistivity in Geophysics. American Association of Physics Teachers, hh. 943-952.

Istadi, B. P., Kadar, A., \& Sawolo, N., 2008. Analysis \& Recent Study Results on East Java Mud Volcano. Subsurface sediment remobilization and fluid flow in sedimentary basins, hh. 53-55. The Petroleum Group.

Loke, M., 1999. Electrical Imaging Surveys for Environmental and Engineering Studies. Penang.
Mazzini, A., Nermoen, A., Krotkiewski, M., Podladchikova, Y., Planke, S., \& Svensen, H., 2009. Strike-Slip Faulting as A Trigger Mechanism for Overpressure Release Through Piercement Structures. Implications for The Lusi Mud Volcano, Indonesia. Marine and Petroleum Geology 26, hh. 1751-1765.

Mazzini, A., Svensen, H., Akhmanov, G., Aloisi, G., Planke, S., Malthe-Sorenssen, A., \& Istadi, B., 2007. Triggering and Dynamic Evolution of The LUSI Mud Volcano, Indonesia. Earth and Planetary Science Letters 261, hh. 375-388.

Sehah, \& Sugito., 2011. Pencitraan Resistivitas 2D Bawah Permukaan Tanaman Jait (Tectona Grandis Sp.) Menggunakan Konfigurasi Wenner (Studi Kasus: Lahan Tanaman Jait Di Belakang Gedung MIPA UNSOED). Berkala Fisika Vol. 14, hh. 1-10.

Widodo, A., 2016, February 15. Benarkah Ada Patahan Watukosek di Bawah Porong? (suara surabaya.net, Interviewer). 


\section{LAMPIRAN}
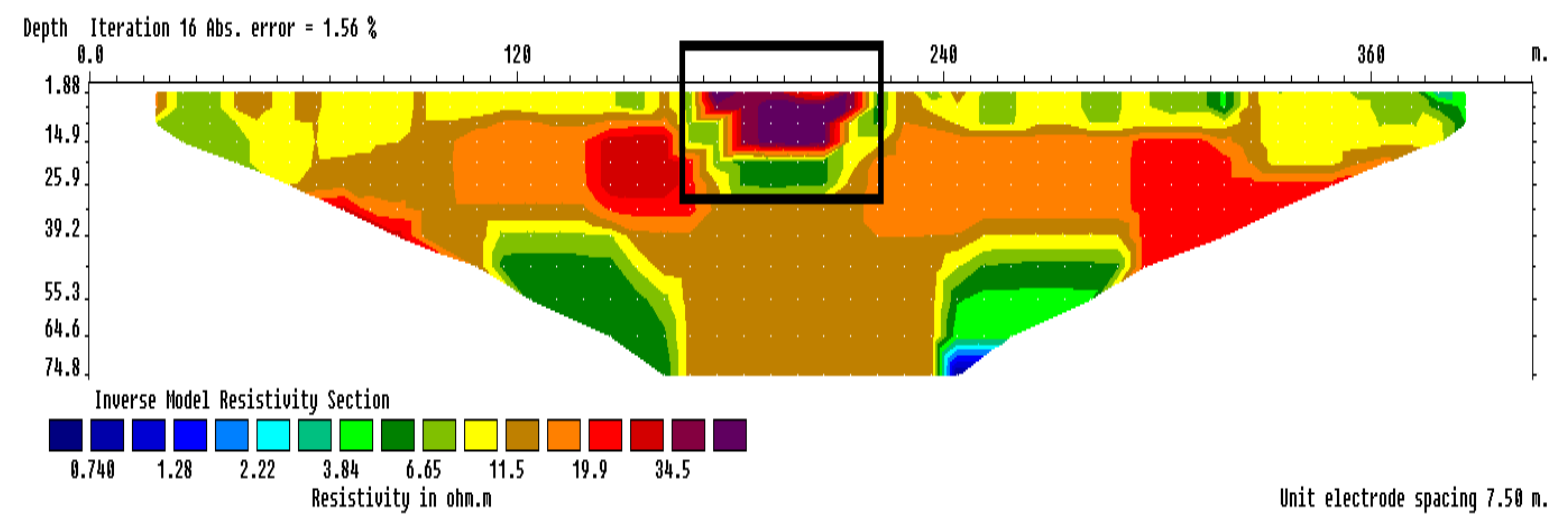

Gambar 6. Penampang 2-D lintasan TG.1
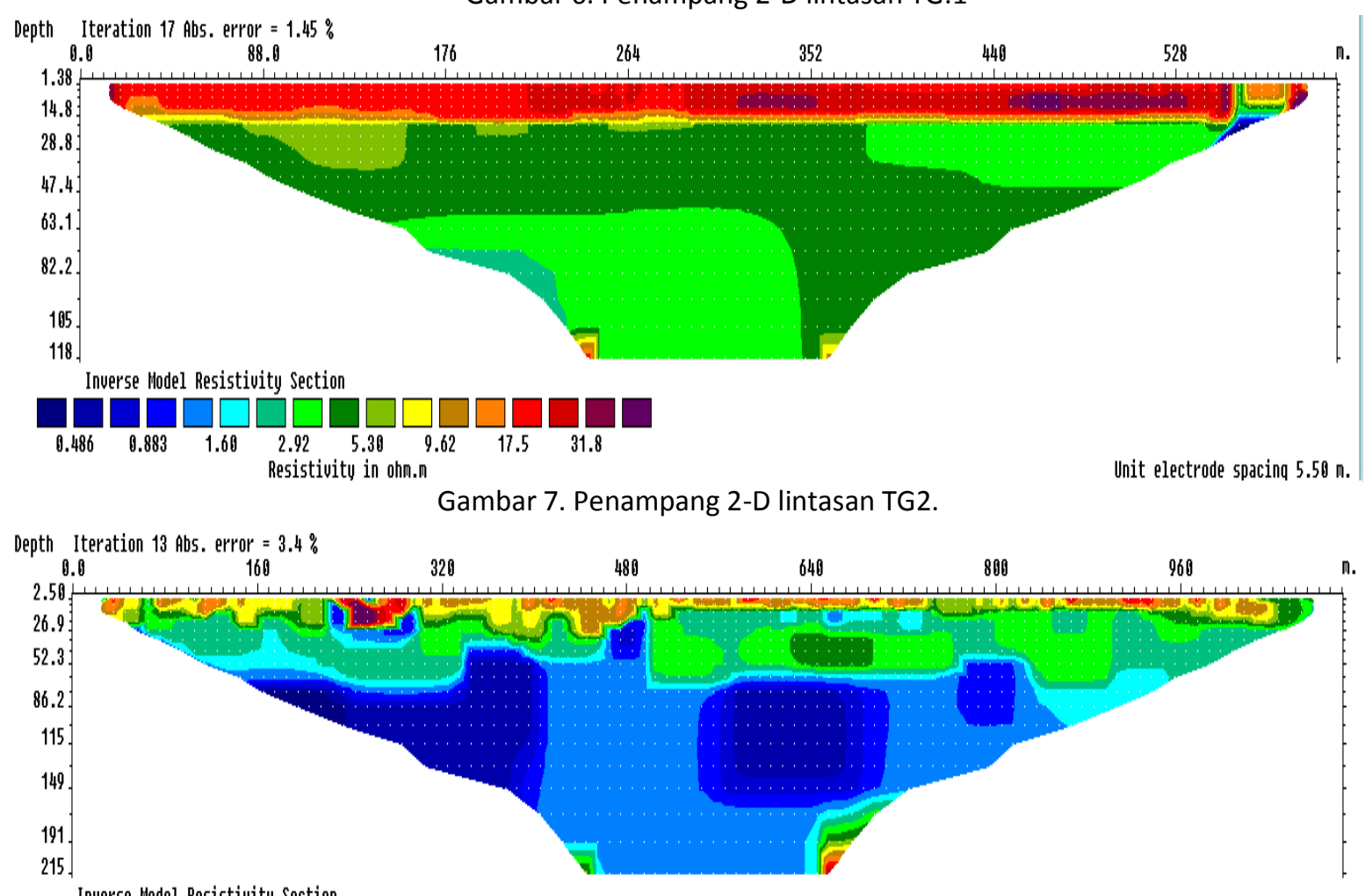

Inverse Model Resistivity Section

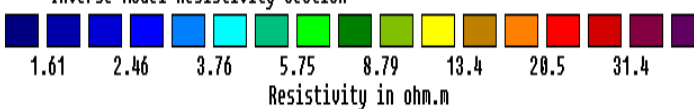

Gambar 8. Penampang 2-D lintasan TG3.

Unit electrode spacing is $10.8 \mathrm{~m}$.

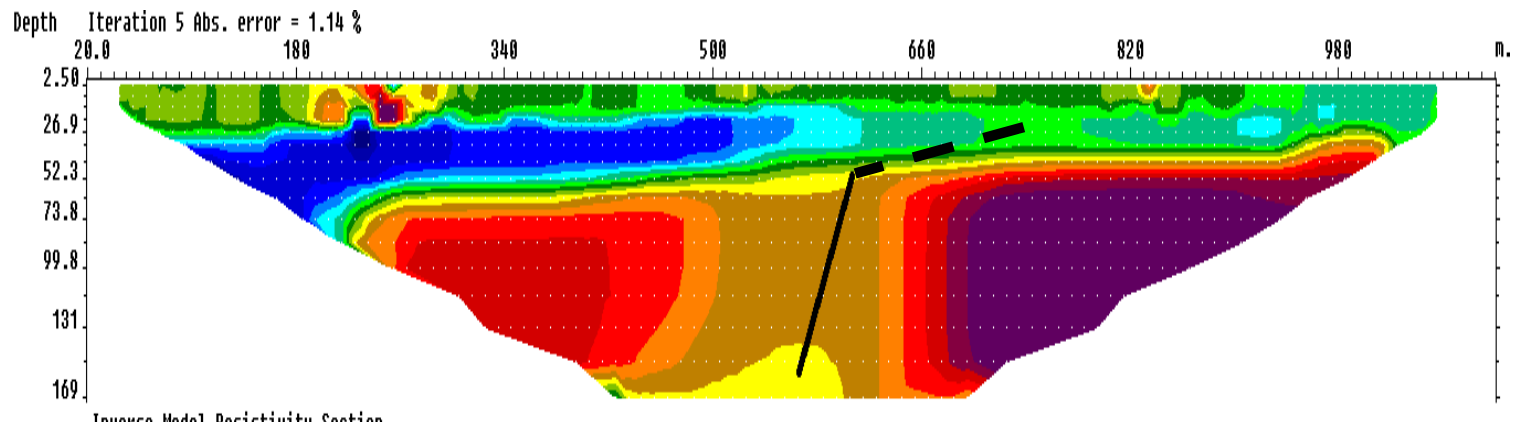

Inverse Hodel Resistivity Section

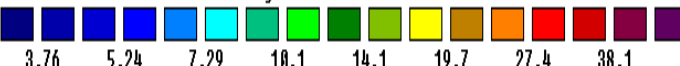

Gambar 9. Penampang 2-D lintasan TG4.

Unit electrode spacing is $10.8 \mathrm{~m}$. 